\title{
DOES LEGISLATION AFFECT ELASMOBRANCH CONSERVATION AND RESEARCH IN BRAZIL? A CASE STUDY FROM PARANÁ STATE
}

\author{
A LEGISLAÇÃO AFETA A CONSERVAÇÃO E PESQUISA DE ELASMOBRÂNQUUOS NO BRASIL? UM ESTUDO \\ DE CASO DOESTADO DO PARANÁ
}

\section{¿LA LEGISLACIÓN AFECTA LA CONSERVACIÓN Y INVESTIGACIÓN DE ELASMOBRANQUIOS EN BRASIL? UN ESTUDIO DE CASO DEL ESTADO DE PARANÁ}

\author{
Natascha Wosnick ${ }^{1}$ \\ Aline Cristina Prado ${ }^{1}$ \\ Eloísa Pinheiro Giareta ${ }^{1}$ \\ Isis Danniele Cury da Cruz \\ Ingrid Hyrycena dos Santos \\ Renata Daldin Leite
}

\begin{abstract}
In Brazil, regulations for elasmobranch fishing are scarce, as well as insufficient monitoring and management. The first catch regulation for the group was published in 1998 (IBAMA No. 121/98). Despite the ban on finning, the legislation provides legal support for evisceration and decapitation prior to landing. Such practices have become particularly problematic for proper monitoring since decharacterization impairs the correct identification of species. In addition, processing is detrimental to research, as many studies rely on sampling of biological material (e.g., blood), posing an additional challenge for researchers using commercial fishing animals for scientific purposes. This study aimed to characterize the frequency of this practice in the fishing of elasmobranchs. The four years of monitoring show that landing patterns of gutted and beheaded animals are influenced by fishing conditions and the catch volumes of the day. We discuss the findings focusing on the need to revise the legal framework for the commercial landing of elasmobranchs and possible promising ways to address this challenge.
\end{abstract}

Keywords: artisanal fishing; processing; evisceration; beheading; endemic species; law.

\section{Resumo}

No Brasil, as regulamentações para a pesca de elasmobrânquios são escassas, além do monitoramento e manejo insuficientes. A primeira regulamentação de captura para o grupo foi publicada em 1998 (IBAMA no 121/98). Apesar da proibição do finning, a legislação suporta legalmente a evisceração e decapitação prévia ao desembarque. Tais práticas tornaram-se particularmente problemáticas para o monitoramento

1 Departamento de Zoologia, Universidade Federal do Paraná, Curitiba - Paraná, Brazil

2 Universidade do Vale de Itajaí, Itajaí - Santa Catarina, Brazil 
adequado, uma vez que a descaracterização prejudica a identificação correta das espécies. Aliado a isso, o processamento acaba prejudicando a pesquisa, já que muitos estudos dependem da amostragem de material biológico (e.g., sangue), representando um desafio a mais para pesquisadores que utilizam animais da pesca comercial para fins científicos. O presente estudo teve como objetivo caracterizar a frequência desta prática na pesca de elasmobrânquios. Os quatro anos de monitoramento mostram que os padrões de desembarque de animais eviscerados e sem cabeça são influenciados pelas condições de pesca e pelos volumes de captura do dia. Discutimos os resultados com foco na necessidade de revisar a estrutura legal para o desembarque comercial de elasmobrânquios e possíveis formas promissoras para lidar com esse desafio.

Palavras-chave: pesca artesanal; processamento; evisceração; descabeçamento; espécies endêmicas; leis.

\section{Resumen}

En Brasil, las regulaciones para pesca de elasmobranquios son escasas, así como un monitoreo y manejo insuficientes. El primer reglamento de captura para el grupo se publicó en 1998 (IBAMA No. 121/98). A pesar de la prohibición del finning, la legislación legalmente apoya la evisceración y la decapitación antes del desembarque. Tales prácticas se han vuelto particularmente problemáticas para un monitoreo adecuado, afectando la identificación correcta de las especies. Además, el procesamiento es perjudicial para la investigación, ya que muchos estudios se basan en el muestreo de material biológico (e.g., sangre), representando un desafío adicional para los investigadores que utilizan animales de pesca con fines científicos. El presente estudio tuvo como objetivo caracterizar la frecuencia de esta práctica en la pesca de elasmobranquios. Los cuatro años de monitoreo muestran que los patrones de desembarque de animales destripado y sin cabeza están influenciados por las condiciones de pesca y los volúmenes de captura del día. Discutimos los hallazgos que se centran en la necesidad de revisar el marco legal para el desembarque comercial de elasmobranquios y las posibles formas prometedoras de abordar este desafío.

Palabras clave: pesca artesanal; procesamiento; evisceración; encabezamiento; especies endémicas; la ley.

\section{INTRODUCTION}

Elasmobranch fishing is a traditional and highly profitable sector both in artisanal and industrial fisheries. The targeted capture of batoids and sharks exhibited the first peak between the mid 3o's and the late 40's (Walker 1998). During the 1940s, several shark fisheries developed in response to the market for hepatic vitamin A. More recently, fisheries have targeted chondrichthyans for their meat, fins, livers, and other byproducts (Stevens et al. 2000). The literature contains many references to the apparent "boom and bust" pattern of these fisheries during the 1940-1970 period (Holden 1974; Anderson 1990; Compagno 1990). However, the concern on 
elasmobranch population status was not taken seriously until the late 8o's (Thorson 1987). The harnessing of elasmobranch meat as the main protein source is a reality in traditional fishing communities in underdevelopment countries. However, in the past decade the consume of shark meat in emergent countries such as Brazil where it is sold as "cação" (Bornatowski et al. 2013, 2018) increased alarmingly. Currently, the South American country is the major shark meat consumer, targeting sharks for domestic trade and importing from countries such as Taiwan, Spain, Uruguay, Argentina, Japan, Costa Rica, Panama and United States (Dent and Clarke 2015). Curiously, most of the exporters are also the most representative countries in the fin trade, leading experts to believe that the finning regulations already implemented in most of the countries cited, are being evaded by encouraging the consume of meat through attractive low prices per kilo (Bornatowski et al. 2018).

Allied to the collapse of several shark populations worldwide, the popular pressure for a ban of finning has led to governmental awareness and as consequence, several domestic and international legislations are being discussed and implemented to supervise the practice (Clarke et al. 2007). Most of the current legislations requires the use of the animal as a whole, or at least its whole retention onboard. For that reason, several countries entitled themselves as finning free nations. However, the extraction of fins after landing and the subsequent trade in countries such as Brazil, Uruguay and India are still permitted, leading to a considerable increase in the shark meat trade as a way to perform finning rightfully, under the justification that the carcasses are being landed and commercialized.

The high level of catches has raised international concern over the sustainability of shark fisheries, however, most of the countries that overexploit local populations have little or no management plans in place for their elasmobranch resources and almost nothing is known about the status of the fishery stocks (Clarke et al. 2007; Dent and Clarke 2015; Barreto et al. 2016). In Brazil, regulations for elasmobranch fishing are scarce, besides insufficient monitoring and management (Barreto et al. 2016) The first ordinance on catch regulation for the group was published in 1998 (IBAMA N. 121/98). In 2012, the ordinance was updated by the Normative Instruction 14, prohibiting landing of animals without the fins attached to the body (i.e., finning) (IN MPA/MMA N. 14/2012). Despite the prohibition, such legislation provided legal support for evisceration and beheading prior to landing. Such measure was intended to allow fishermen to discard products of low commercial interest thus reducing the total weight on board.

In order to evaluate elasmobranch commercial capture and trade patterns, data from landings in Southern Brazil was collected. 


\section{MATERIAL AND METHODS}

Data collection was carried out in Paraná state, Southern Brazil (Figure 1). In the coast of Paraná, according to data collected between 1980 and 1994, about $6.4 \%$ of the total production from the artisanal sector was consisted of elasmobranchs. This value exceeded the specific catch values of the teleosts with commercial interest, such as hake (5.9\%) and mullet (5.1\%) (Paiva 1997). It is known that in some fishing gears, such as bottom gillnet, the average percentage represented by elasmobranchs in total caught ranges from $2.3 \%$ to $28.7 \%$ of the mass, depending on the mesh employed (Bornatowski and Abilhoa 2012). However, the state of Paraná has recent fishing statistics from the Fisheries Monitoring Program (Administração dos Portos de Paranaguá e Antonina 2019), but is still very incipient in the artisanal sector and does not cover all coastal fishing communities, and the fishing data for elasmobranchs are often not quantified and therefore remain underestimated.

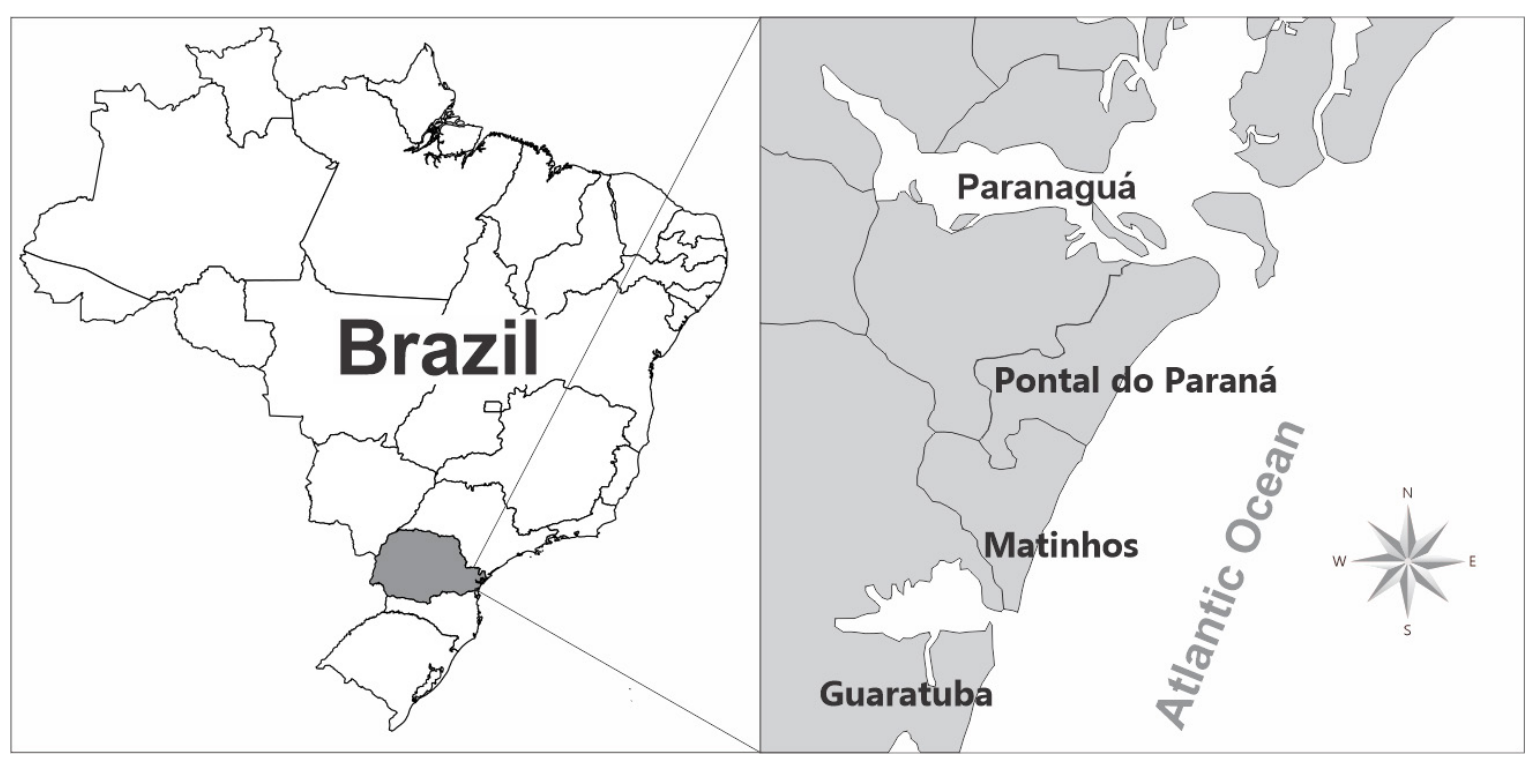

Figure 1. Map of the study region - Paraná Coast, Southern Brazil.

Monthly observations of artisanal fishing landings were made between 2015 and 2018. At each landing, elasmobranchs were counted with or without head and with or without viscera. For headless animals, species identification was based on the popular names that the fishermen of the region use, besides identification detailed by the team through identification characters already established in the literature (e.g., Gomes et al. 2010; Bornatowski and Abilhoa 2012). 


\section{RESULTS}

Along the four years of monitoring (2015-2018), 330 animals were accounted beheaded and/or eviscerated at various stages of life (Figure 2). However, this value is underestimated as not all landings were followed.

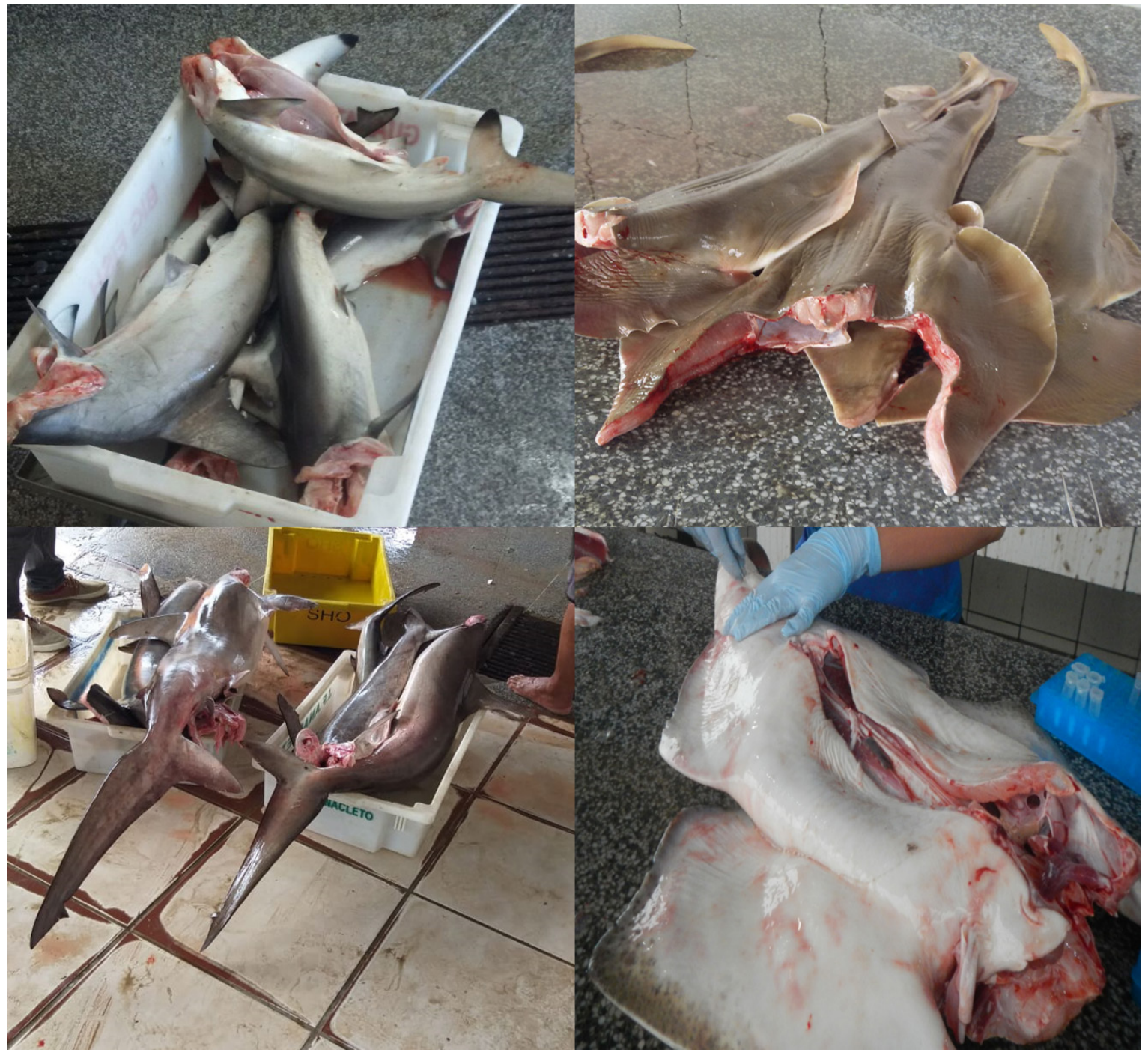

Figure 2. Sharks and batoids commonly landed beheaded and eviscerated.

Rhizoprionodon spp., Pseudobatos spp., Squatina spp., Sphyrna spp. and Carcharhinus limbatus were the species with larger volumes landed already processed (Figure 2). Considering all landings (both massive and punctual) monitored, Sphyrna spp. were the most representative (58\%), being always beheaded and eviscerated. Rhizoprionodon spp. and Pseudobatos spp., were already beheaded and/or eviscerated in $18 \%$ and $14 \%$ of observations, respectively. Squatina spp., were counted in lower volumes and were landed beheaded and/or eviscerated in $5 \%$ of observations. $C$. limbatus were landed fully processed only in $4 \%$ of observations. Lastly, one Galeocerdo cuvier was also landed beheaded and eviscerated (Figure 3). 


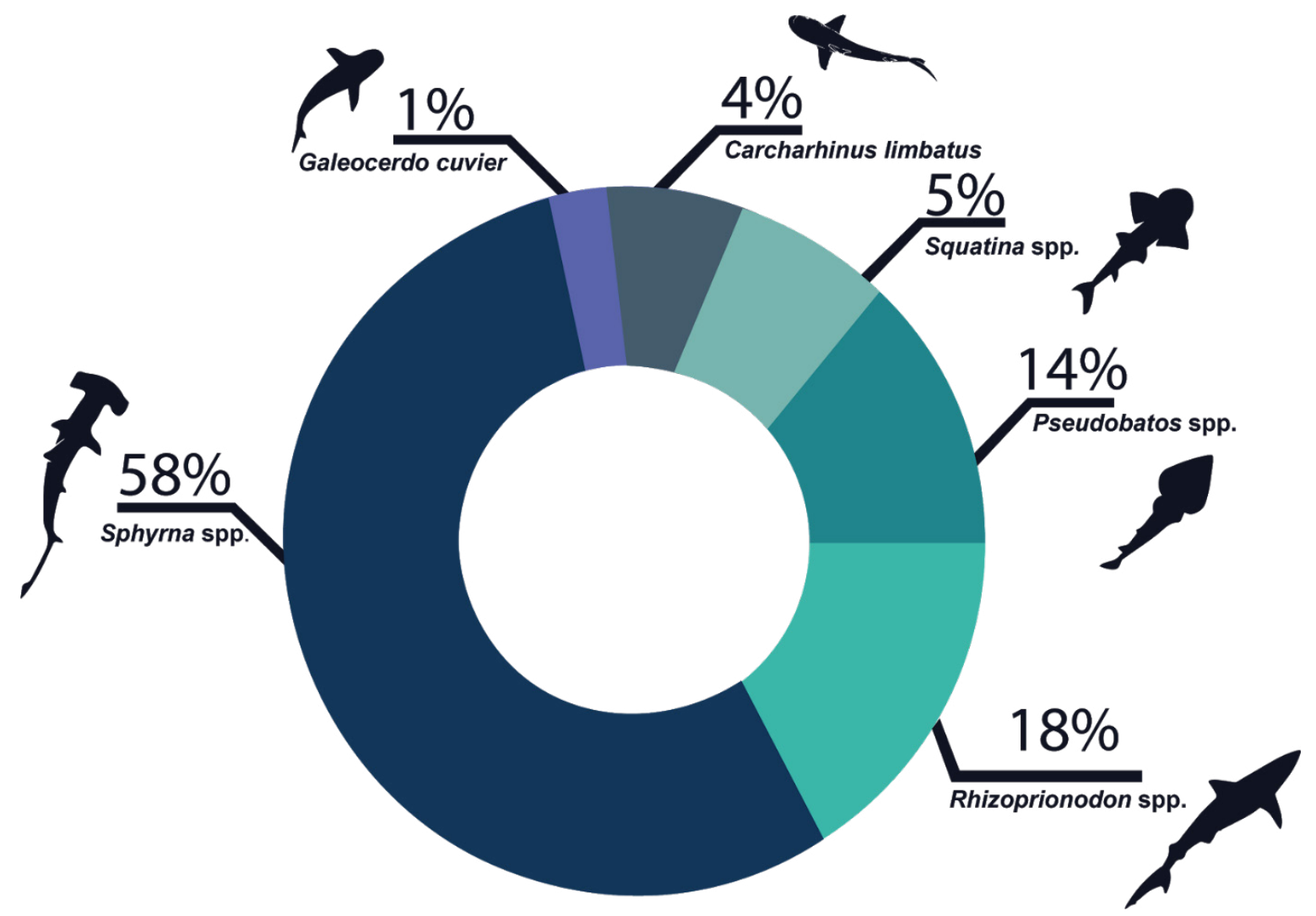

Figure 3. Species most commonly landed between 2015 and 2018 and their respective percentages of onboard processing. All landings monitored were considered.

Apart from the species cited above, other elasmobranchs were landed during the period between 2015 and 2018, such as Aetobatus narinari, Narcine brasiliensis, Hypanus guttatus, Zapteryx brevirostris, Atlantoraja castelnaui, Gymnura altavela, Rhinoptera spp., Carcharhinus obscurus, C. plumbeus and Isurus oxyrinchus. In all observations, all specimens were landed whole.

\section{DISCUSSION}

Here, we present data collected in a four-year survey, demonstrating that the landing of processed animals occurs constantly. In Brazil, the decharacterization prior to landing is not restricted to elasmobranchs, with reports for the Goliath grouper (Epinephelus itajara). Before landing, the animals are beheaded and have their skin removed to evade inspection (Giglio et al. 2014). In our survey, only angelsharks were landed without skin. Also, the landing of beheaded and eviscerated animals is not restricted to large-scale industrial fishing. It is also reported in small-scale fisheries, a sector even more neglected in terms of monitoring. While large-scale fisheries are responsible for alarming capture volumes of adults, coastal fisheries, normally related to the artisanal sector, tend to capture elasmobranchs in earlier life-stages 
and/or pregnant females that approach the coast to give birth (Bornatowski and Abilhoa 2012), making the conservation of coastal species, a matter of participative management with artisanal fishermen.

While some artisanal fishermen claim that land of headless sharks is intended to prevent gillnet damage during the animal's removal, others claim that the practice reduces on-board weight. However, this pattern seems to change according to the time of day the boat returns, how many hours the fishermen were at sea and the volume of animals captured. Such practice is allowed and encouraged not only by domestic but also international legislation for extraction and commercialization, since any elasmobranch species can be beheaded, skinned and gutted prior to landing. Still, none of the fishermen seemed to be aware of the legality of the practice, which are widely used but with everyone in the community afraid to do so. Interestingly, fishing in the region occurs incidentally for most species, and landing is currently permitted under these terms if recovery plans are in place for the species caught (MMA Ordinance No. 73/2018), emphasizing again the importance of participatory studies in order to generate data that benefit species conservation without harming fishing communities.

Onboard decharacterization became particularly problematic in two distinct scenarios: (1) fisheries management in a conservationist perspective and (2) elasmobranch basic research. With regard to fisheries management, the decharacterization of elasmobranchs prior to landing primarily affects monitoring (Vooren and Klipper 2005). The exclusion of shark heads onboard is especially problematic for species like hammerheads, angelsharks and guitarfishes, once the cephalic differences are an easily recognizable criteria, being traditionally used for quick identification. Even when those species are landed with the head, the correct identification at species level has proved to be difficult to perform by inexperienced inspectors, with fishing statistics often presenting species grouped into the same general category ("cação" for sharks and "arraia” for batoids) (Abercrombie et al. 2005). To set efficient management plans, knowledge on the current status of elasmobranch populations, as well as local fishing profiles are necessary, since capture patterns may vary based on regional protocols (Coll et al. 2013; Bradai et al. 2018). Speciesspecific fishery statistics, together with biological and ecological data, are essential for determining priority management actions for ecosystems (Davidson et al. 2016; Barletta et al. 2017; Gemaque et al. 2017). Thus, the proper identification of species that are being harvested must be ensured by both national and international legislation.

Besides that, the decharacterization may impair minimum capture size estimates based on biometric data. Published in 2005, the Normative Instruction No. 53 (MMA) establishes a different approach for beheaded elasmobranchs. While the minimum size for capture for whole animals is based on total length, biometrics of beheaded animals are performed according to the distance between the anterior end of the base of the first dorsal fin and the posterior end of the base of the second dorsal fin (for sharks in general). For beheaded angelsharks, estimation is made by the distance between the anterior end of the pectoral fin and the anterior end of the 
base of the first dorsal fin. For batoids, there is no minimum capture size, whether landed whole or already processed (minimum capture size for Pseudobatos spp. was featured at IBAMA Ordinance No. 73/2003 which was repealed by Ordinance No. 53/2005). It is possible that such practice, even if permitted by legislation, is undermining the establishment of minimum catch sizes for new species as well as making it difficult to evaluate if animals are within the permitted sizes. This is because often sharks and batoids are landed very torn, impairing data quality and making carcasses measurement subjective and error-prone.

Allied to the subjectivity of minimum carcass sizes, basic biological data such as weight, total length to evaluate growth rate and stock valuation models (Domingues et al. 2016), life stage, and morphometrics are highly impaired and even impossible to estimate. A clear example that processing is detrimental to research is the study published by Hérron et al. (2019), where $80 \%$ of the sampled animals were beheaded, eviscerated or both, requiring the application of weight correction factors, which are not available for all species. In the case of Paraná, physiological studies have been impaired, since even if blood samples can be taken from processed animals (i.e., spinal puncture), it is not yet known whether the sampled blood is in ideal conditions for analysis due to possible coagulation and biochemical alterations caused by processing and post-processing time. Evisceration on board leads to discarding samples of extreme importance for applied studies as diet/feeding dynamics and reproduction/growth data are lost (Vogler et al. 2003; Torres-Rojas et al. 2010).

DNA barcoding has been a promising tool for the identification of species being trade (Staffen et al. 2017; Bunholi et al. 2018; Feitosa et al. 2018). However, the methodology, besides being expensive, requires very specific and contaminationfree protocols which is often difficult to perform in the field. Although, there is a new, quick and cheaper version being used named "Multiplex real-time PCR" $(<4$ hours and \$0.94 USD per sample), being capable to detect nine of the twelve sharks listed under CITES in a single reaction (Cardeñosa et al. 2018), but still depends on a good workstation in field to support all the equipment's and a source of electricity to cover all these elements, prerequisites scarcely found in field of most regions of Brazil. Still, not all species are barcoded and available for comparison (Kolmann et al. 2017). Some even cheaper alternatives are available such as the software's created to allow an accurate identification through the use of fins photos (e.g., iSharkFin). However, the application is limited to dorsal fins of 35 shark species and pectoral fins of 7 species commonly seen in international trade, including some species listed in the CITES Appendices (FAO 2019). Still, its use needs proper training plus fins still attached to the body, making the implementation far from the Brazilian reality.

Thus, is clear that although processing on board is legally allowed and justified by fishermen, this practice is highly detrimental to the correct identification of species, scientific research and consequently monitoring of fishing stocks, affecting not only researchers and policy makers, but also fishermen who depend on healthy stocks to keep performing their activities. In addition, a large volume of 
biological samples and potential scientific investigations are being lost due to the decharacterization of landed animals. In Brazil, where commercial fishing is heavily relied on to conduct research, this scenario is particularly worrying and detrimental. Given this, the integration between researchers and fishermen is imperative and becomes a two-way street. From the research point of view, fishermen's participatory monitoring could assist in the collection of ecological and biological data. On the other hand, fishermen would be aware of and closer to the academy, as well as being updated about current legislation, and may even assist in changes and improvements in fisheries management, thus assisting in elasmobranch conservation.

\section{CONCLUSION}

Regardless of the breach of the law, to allow the landing of eviscerated and beheaded animals, it is important to emphasize the urgent need to include traditional communities in elasmobranch research, thus boosting awareness and willingness to participate in conservation actions, as well as the implementation of an incipient surveillance (Giglio et al. 2014; PAN Tubarões 2014). The data collected during this study are of utmost importance to discuss the problematic in Brazil's legislation breaches, assist in the management and conservation plans not only of elasmobranchs, but also for other groups of fish that are decharacterized, like the Goliath grouper (Epinephelus itajara).

The establishment of good relations between researchers, society, fishing communities and the State is vital for the creation of effective public policies for all. So that access to materials obtained by fishing communities can be transformed into data/ information for the scientific community, which will be passed on to the appropriate authorities, and will eventually return to society, through environmental education projects, the creation of good practices manuals, identification guides for fishermen and environmental inspectors, the commercialization of sustainable fishing resources, efficient environmental laws and proper monitoring. Finally, the present study also aims to encourage researchers from other regions of Brazil to monitor elasmobranch landings and commercialization, in order to gather information for the National Action Plan for the Conservation of Endangered Sharks and Marine Batoids.

\section{ACKNOWLEDGEMENTS}

Authors would like to thank the artisanal fishermen for their active participation in elasmobranch studies carried out through the past seven years. Natascha Wosnick would like to thank CAPES and the Postgraduate Program in Zoology at UFPR for the postdoctoral fellowship awarded. Finally, the authors would like to thank Associação MarBrasil and Petrobras for their logistical support through the REBIMAR program. 


\section{REFERENCES}

Abercrombie DL, Clarke SC, Shivji MS. 2005. Global-scale genetic identification of hammerhead sharks: application to assessment of the international fin trade and law enforcement. Conservation Genetics, 6(5): 775-788. http://doi.org/10.1007/s10592005-9036-2

Administração dos Portos de Paranaguá e Antonina (APPA). 2019. In: Governo do Estado do Paraná, Secretaria de Infraestrutura e Logística. Disponível em: http:// www.portosdoparana.pr.gov.br/ Acesso em: 28 out 2019.

Anderson ED. 1990. Estimates of large shark catches in the Western Atlantic and Gulf of Mexico, 1960-1986. In: Elasmobranchs as Living Resources: Advances in the Biology, Ecology, Systematics, and the Status of the Fisheries. Proceedings of the Second United States-Japan Workshop East-West Center, Honolulu, Hawaii, 9-14 December 1987, pp. 443-454. Ed. by H. L. Pratt, S. H.Gruber, and T. Taniuchi. NOAA Technical Report NMFS, 90. 518 pp.

Barletta M, Lima AR, Dantas DV, Oliveira IM, Neto JR, Fernandes CAF, Farias EGG, Filho JLR, Costa MF. 2017. How can accurate landing stats help in designing better fisheries and environmental management for Western Atlantic estuaries?. In: Coastal Wetlands: Alteration and Remediation, Springer, Cham, 631-703.https://doi. org/10.1007/978-3-319-56179-0 20

Barreto R, Ferretti F, Flemming JM, Amorim A, Andrade H, Worm B, Lessa R. 2016. Trends in the exploitation of South Atlantic shark populations. Conservation Biology, 30: 792-804.https://doi.org/10.1111/cobi.12663

Bornatowski H, Abilhoa V. 2012. Tubarões e raias capturados pela pesca artesanal no Paraná: guia de identificação. Hori Consultoria Ambiental. Hori Cadernos Técnicos, $\mathrm{n}^{\circ}$ 4. $124 \mathrm{pp}$.

Bornatowski H, Braga RR, Vitule JRS. 2013. Shark mislabeling threatens biodiversity. Science, 340(6135): 923-923.https://doi.org/10.1126/science.340.6135.923-a

Bornatowski H, Braga RR, Barreto RP. 2018. Elasmobranchs Consumption in Brazil: Impacts and Consequences. Advances in Marine Vertebrate Research in Latin America, 251-262. https://doi.org/10.1007/978-3-319-56985-7 10

Bradai MN, Saidi B, Enajjar S. 2018. Overview on Mediterranean Shark's Fisheries: Impact on the Biodiversity. Marine ecology: Biotic and abiotic interactions, 211-230. http://dx.doi.org/10.5772/intechopen.74923 
Bunholi IV, da Silva Ferrette BL, De Biasi JB, de Oliveira Magalhães C, Rotundo MM, Oliveira C, Foresti F, Mendonça FF. 2018. The fishing and illegal trade of the angelshark: DNA barcoding against misleading identifications. Fisheries Research, 206: 193-197. https://doi.org/10.1016/i.fishres.2018.05.018

Cardeñosa D, Quinlan J, Shea KH, Chapman DD. 2018. Multiplex real-time PCR assay to detect illegal trade of CITES-listed shark species. Scientific Reports, 8: 1-10. https:// doi.org/10.1038/s41598-018-34663-6

Clarke S, Milner-Gulland EJ, Bjørndal T. 2007. Social, economic, and regulatory drivers of the shark fin trade. Marine Resource Economics, 22(3):305-327.

Coll M, Navarro J, Palomera I. 2013. Ecological role, fishing impact, and management options for the recovery of a Mediterranean endemic skate by means of food web models. Biological Conservation, 157: 108-120.https://doi.org/10.1016/j.biocon.2012.06.029

Compagno LJV. 1990. Shark exploitation and conservation. In: Elasmobranchs as Living Resources: Advances in the Biology, Ecology, Systematics, and the Status of the Fisheries. Proceedings of the Second United States-Japan Workshop East-West Center, Honolulu, Hawaii, 9-14 December 1987, pp. 391-414. Ed. by H. L. Pratt, S. H.Gruber, and T. Taniuchi. NOAA Technical Report NMFS, 90. 518 pp.

Davidson LNK, Krawchuk MA, Dulvy NK. 2015. Why have global shark and ray landings declined: improved management or overfishing?. Fish and Fisheries, 17(2): 438-458. https://doi.org/10.1111/faf.12119

Dent F, Clarke S. 2015. State of the global market for shark products. FAO Fisheries and Aquaculture Technical Paper (FAO), ed. 590.

Domingues RR, Caltabellotta FP, Amorim AF. 2016. Length-length and lengthweight relationships of Carcharhinus falciformis and $C$. signatus (Carcharhinidae: Carcharhinus) caught by commercial fisheries in the Southwest Atlantic Ocean. Regional Studies in MarineScience, 6:83-86.https://doi.org/10.1016/i.rsma.2016.03.014

Dulvy NK, Simpfendorfer CA, Davidson LNK, Fordham SV, Bräutigam A, Sant G, Welch DJ. 2017. Challenges and Priorities in Shark and Ray Conservation. Current Biology, 27(11): 565-572. https://doi.org/10.1016/j.cub.2017.04.038

FAO. International plan of action for the conservation and management of sharks. 2019. Web site. iSharkFin. FI Institutional Websites. In: FAO Fisheries and Aquaculture Department. Rome. Available in: http://www.fao.org/ipoa-sharks/tools/software/ isharkfin/en Access in: 23 jul 2019. 
Feitosa LM, Martins APB, Giarrizzo T, Macedo W, Monteiro IL, Gemaque R, Nunes JLS, Gomes F, Schneider H, Sampaio I, Souza R, Sales JB, Rodrigues-Filho LF, Tchaicka L, Carvalho-Costa LF. 2018. DNA-based identification reveals illegal trade of threatened shark species in a global elasmobranch conservation hotspot. Scientific Reports, 8: 3347.https://doi.org/10.1038/s41598-018-21683-5

Gemaque R, Monteiro ILP, Gomes F, Sodré D, Sampaio I, Sales JBL, Rodrigues-Filho LFS. 2017. Why implement measures to conserve the diversity of Elasmobranchs? The case of the northern coast of Brazil. Revista da Biologia, 17(2): 1-7._http://doi. org/10.7594/revbio.17.02.01

Giglio VJ, Bertoncini ÁA, Ferreira BP, Hostim-Silva M, Freitas MO. 2014. Landings of goliath grouper, Epinephelus itajara, in Brazil: despite prohibited over ten years, fishing continues. Natureza \& Conservação, 12(2): 118-123.https://doi.org/10.1016/j. ncon.2014.09.004

Gomes UL, Signori CN, Gadig OB, Santos HR. 2010. Guia para identificação de tubarões e raias do Rio de Janeiro. Technical Books, Rio de Janeiro. 236 pp.

Herrón P, Stäbler M, Castellanos-Galindo G, Díaz JM, Wolff M. 2019. Towards ecosystem-based assessment and management of small-scale and multi-gear fisheries: insights from the tropical eastern Pacific. Frontiers in Marine Science, 6: 127. https:// doi.org/10.3389/fmars.2019.00127

Holden MJ. 1974. Problems in the rational exploitation of elasmobranch populations and some suggested solutions. Sea Fisheries Research, 117-137.

Iglésias SP, Toulhoat L, Sellos DY. 2010. Taxonomic confusion and market mislabeling of threatened skates: important consequences for their conservation status. Aquatic Conservation, 20(3):319-33.https://doi.org/10.1002/aqc.1083

Kolmann MA, Elbassiouny AA, Liverpool EA, Lovejoy NR. 2017. DNA barcoding reveals the diversity of sharks in Guyana coastal markets. Neotropical Ichthyology, 15(4). https://doi.org/10.1590/1982-0224-20170097

Ministério de Estado da Pesca e Aquicultura - MPA/Ministério do Meio Ambiente MMA. 2012. Instrução Normativa n. 14, de 26 de novembro de 2012. Diário Oficial da União, 1: 34-35.

Ministério do Meio Ambiente - MMA. 1998. Portaria n. 121-N, de 24 de agosto de 1998. Diário Oficial da União. 
Paiva MP. 1997. Recursos pesqueiros estuarinos e marinhos do Brasil. UFC Edições, Fortaleza. 278 pp.

PAN Tubarões - Plano de Ação Nacional para a Conservação dos Tubarões e Raias Marinhos Ameaçados de Extinção. 2014. ICMBio - Instituto Chico Mendes de Conservação da Biodiversidade, Brasília. Disponível em: http://www.icmbio.gov.br/ portal/images/stories/docs-plano-de-acao/pan-tubaroes/Sumario-pan-tubaroesraias-site.pdf_Acesso em: 24 jul 2019.

Staffen CF, Staffen MD, Becker ML, Lofgren SE, Muniz YCN, de Freitas RHA, Marrero AR. 2017. DNA barcoding reveals the mislabeling of fish in a popular tourist destination in Brazil. Peerj, 5.https://doi.org/10.7717/peerj.4006

Stevens JD, Bonfil R, Dulvy NK, Walker PA. 200o. The effects of fishing on sharks, rays, and chimaeras (chondrichthyans), and the implications for marine ecosystems. ICES Journal of Marine Science, 57: 476-494.https://doi.org/10.1006/jmsc.2000.0724

Thorson TB. 1987. Human impacts on shark populations. In: Cook, SF. (ed.) Sharks - an injury into biology, behavior, fisheries and use. Oregon State University, USA. $31-37$

Torres-Rojas YE, Hernández-Herrera A, Galván-Magaña F, Alatorre-Ramírez VG. 2010. Stomach content analysis of juvenile, scalloped hammerhead shark Sphyrna lewini captured off the coast of Mazatlán, Mexico. Aquatic Ecology, 44(1): 301-308. https:// doi.org/10.1007/s10452-009-9245-8

Vögler R, Milessi AC, Quiñones RA. 2003. Trophic ecology of Squatina guggenheim on the continental shelf off Uruguay and northern Argentina. Journal of Fish Biology, 62(6): 1254-1267. https://doi.org/10.1046/j.1095-8649.2003.00105.X

Vooren CM, Klippel S. 2005. Diretrizes para a conservação de espécies ameaçadas de elasmobrânquios. Ações para a conservação de tubarões e raias no sul do Brasil, 213228.

Walker TI. 1998. Can shark resources be harvested sustainably? A question revisited with a review of shark fisheries. Marine and Freshwater research, 49(7): 553-572. 